ORIGINAL ARTICLE / ARTIGO ORIGINAL

\title{
Bullying and associated factors among Brazilian adolescents: analysis of the National Adolescent School-based Health Survey (PeNSE 2012)
}

\section{Bullying e fatores associados em adolescentes brasileiros: análise da Pesquisa Nacional de Saúde do Escolar (PeNSE 2012)}

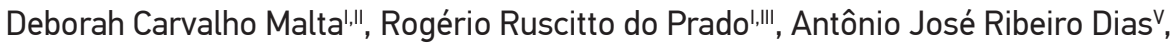 \\ Flavia Carvalho M. Mello'v , Marta Angelica lossi Silvalv, Michelle Ralil da Costa", \\ Waleska Teixeira Caiaffa"
}

\begin{abstract}
Objective: To estimate the prevalence of bullying from the victim's perspective in Brazilian school children and to analyze its association with individual and family context variables. Methods: An analysis of the data on 109,104 adolescents, obtained by the National Adolescent School-based Health Survey, held in schools in 2012, was carried out. An association model between bullying and explanatory variables was tested in different contexts: sociodemographic, risk behaviors, mental health and family context. Univariate and multivariate analyzes were performed, calculating the Odds Ratio and confidence intervals. Results: The prevalence of bullying found in this study was of $7.2 \%$ (95\% CI $6.6-7.8)$. A higher chance of bullying was found among male students $(\mathrm{OR}=1.58 ; 95 \% \mathrm{CI} 1.51-1.66)$, with an inverse relation between age and bullying, with the magnitude of risk among adolescents younger than 13 years of age being higher when compared to those with 16 years of age or more. Of individual risk behaviors, only being a smoker remained in the final model $(\mathrm{OR}=1.11$; $95 \% \mathrm{CI} 1.01-1.23)$. Mental health variables associated with bullying were: feeling lonely $(\mathrm{OR}=2.66 ; 95 \% \mathrm{CI}$ $2.52-2.81)$, insomnia $(\mathrm{OR}=1.92 ; 95 \% \mathrm{CI} 1.80-2.05)$, not having friends (OR $=1.71 ; 95 \% \mathrm{CI} 1.54-1.89)$, and, in the family context, those who skip class without telling their parents $(\mathrm{OR}=1.13 ; 95 \% \mathrm{CI} 1,07-1,19)$ and those who suffer physical abuse by family members (OR $=2.03 ; 95 \% \mathrm{CI} 1.91-2.146)$. Conclusion: Bullying was associated to male students, younger, of black color, smokers, with mental health vulnerabilities and victims of domestic violence. This suggests the need for a holistic approach from education and health professionals, parents and the community in seeking measures for the prevention of bullying.
\end{abstract}

Keywords: Violence. Bullying. Adolescent. Schools. Mental health. Family.

'Department of Non-Communicable Diseases Surveillance and Health Promotion, Ministry of Health - Brasília (DF), Brazil.

"Universidade Federal de Minas Gerais - Belo Horizonte (MG), Brazil.

"'Universidade de São Paulo - São Paulo (SP), Brazil.

vNursing school at Universidade de São Paulo - Ribeirão Preto (SP), Brazil.

vBrazilian Institute of Geography and Statistics - Rio de Janeiro (RJ), Brazil.

Corresponding author: Deborah Carvalho Malta. Departamento de Vigilância de Doenças e Agravos Não Transmissíveis e Promoção da Saúde. Secretaria de Vigilância em Saúde. Ministério da Saúde. SAF Sul, Trecho 2, Lote 5/6, Torre I, Edifício Premium, Sala 14, Térreo, CEP: 70070-600, Brasília, DF, Brasil. E-mail: deborah.malta@saude.gov.br

Conflict of interests: nothing to declare - Financing source: none. 
RESUMO: Objetivo: Estimar a prevalência de bullying, sob a perspectiva da vítima, em escolares brasileiros e analisar sua associação com variáveis individuais e de contexto familiar. Métodos: Foram analisadas informações de 109.104 adolescentes obtidas da Pesquisa Nacional de Saúde do Escolar (PeNSE), 2012. Foi testado modelo de associação entre o bullying e variáveis explicativas nos seguintes domínios: sociodemográfico, comportamentos de risco, saúde mental e contexto familiar. Foram feitas analises uni e multivariada, calculando-se os odds ratio e respectivos intervalos de confiança. Resultados: A prevalência de bullying foi de 7,2\% (IC95\% 6,6-7,8). Maior chance de bullying foi encontrada entre escolares do sexo masculino (OR = 1,58; IC95\% 1,51 - 1,66), com uma relação inversa entre idade e bullying, sendo maior a magnitude do risco entre menores de 13 anos quando comparados aos de 16 ou mais anos. Dos comportamentos de risco individuais, apenas ser fumante se manteve no modelo final (OR = 1,11; IC95\% 1,01-1,23). As variáveis de saúde mental associadas foram: sentir-se solitário $(\mathrm{OR}=2,66$; IC95\% 2,52-2,81), ter insônia (OR = 1,92; IC95\% 1,80 - 2,05), não ter amigos (OR = 1,71; IC95\% 1,54-1,89) e, no contexto familiar os que faltam às aulas sem avisar os pais (OR = 1,13; IC95\% 1,07-1,19) e relataram sofrer agressão física dos familiares (OR = 2,03; IC95\% 1,91 - 2,16). Conclusão: O bullying mostrou-se associado aos escolares do sexo masculino, mais jovens, de cor preta, fumantes, além daqueles que apresentam vulnerabilidades no campo da saúde mental e de violência doméstica, o que sugere necessidade de uma abordagem holística de profissionais da educação, saúde, pais e comunidade na busca de medidas para sua prevenção.

Palavras-chave: Violência. Bullying. Adolescentes. Escolas. Saúde mental. Família.

\section{INTRODUCTION}

Bullying (which means tough guy) comprehends behaviors with several levels of violence, which range from annoyance and hostile attitudes to clear aggression, be it verbal or not. Intentional and repeated aggressions, without an apparent motivation, can be caused by one or more individuals in relation to others, therefore causing pain, distress, exclusion, humiliation, discrimination, among others ${ }^{1,2}$.

It is an intentional act that leads to the victimization of the other person, be it physical or psychological, which can result in acts of exclusion and rumors and involve physical violence, such as the acts of hitting and kicking. Under the victim's point of view, the term of victimization ${ }^{3-5}$ has been adopted. The behavior is manifested by repeated acts of oppression, discrimination, intimidation, cursing, jokes, tyranny, and aggression to people or groups $\mathrm{s}^{3-5}$.

Bullying has been widely studied in the school environment, and it should be dealt with by aiming at its overcoming and the construction of a healthy environment ${ }^{6}$. A study by the World Health Organization among adolescents identified, in average a prevalence of $14 \%$ of victimization caused by bullying among 13 year-old adolescents, even though there is great variation between countries. The highest frequency is in Lithuania (29\%), and the 
lowest one is in Sweden (4.5\%) $)^{7}$. In Brazil, a sample of 5,168 students from the fifth to the eighth grades of public and private schools in the five regions of the country characterized bullying as more than three aggressions in that year, by adopting the presupposition that it is not an isolated action, and identified $12.5 \%$ of victims ${ }^{8}$.

Even though there are many studies that analyze the results of the study by WHO in the world, in Brazil there are still only a few studies, and most of them presents descriptive analyses ${ }^{2,6,8}$, being restricted to individual characteristics.

It is important to understand factors that are associated with bullying, in order to search for a theoretical model for its complex inter-relations. Authors have described its association with the male gender, with younger students ${ }^{7,9}$, and there are more reports in school environments and in more socially vulnerable urban areas ${ }^{10}$. In spite of that, in the National Adolescent School-based Health Survey, in 2009, in Brazilian capitals there was no difference between its prevalence according to type of public or private school, used as proxy of socioeconomic level ${ }^{11}$.

Other studies indicate family as the essential locus for the development of children and adolescents, and the following were described as protective factors: family supervision, being aware of children's whereabouts in their free time and other attitudes. Practices such as missing classes without notifying the parents are seen as risk markers ${ }^{11-13}$. Situations such as family abuse have been pointed out as being associated with bullying, thus predisposing to victimization ${ }^{14}$. Individual aspects have also been associated with bullying as risk behaviors, such as use of tobacco, alcohol and drugs, besides risk sexual behavior ${ }^{9}$ and mental health issues, including reports of loneliness, symptoms of depression (including feelings of sadness and desperation), insomnia and suicidal ideation. The hypothesis is that having suffered bullying may be associated with multiple factors, which get potentialized and interpenetrated. Therefore, understanding these aspects may be the basis for preventive measures.

In the National Adolescent School-based Health Survey, in 2012, victimization caused by bullying was analyzed, and there was the insertion of themes such as mental health, therefore enabling to the performance of further analyses.

Facing the exposed, the objective of this study is to analyze the association between bullying, sociodemographic variables, individual risk behaviors, mental health and family context behavior.

\section{METHODS}

It is a cross-sectional study with information from the National Adolescent Schoolbased Health Survey (PeNSE conducted in 2012. PeNSE investigated behavioral risk and protective factors in relation to health in a sample of $9^{\text {th }}$ grade students in elementary school, in daytime shifts of public or private schools located in urban or rural zones of a set of cities in the Brazilian territory. The $9^{\text {th }}$ grade of elementary school was chosen because at this stage students have enough knowledge to answer the self-applicable questionnaire, 
besides the proximity to the age of reference (13 to 15 years old) established by the World Health Organization (WHO).

The database of the School Census 2010 was used, besides lists of schools that reported having $9^{\text {th }}$ grade classes in their daily shifts. The sample was measured in order to estimate population parameters (proportions or prevalence) in several geographic domains, comprehending the 26 State capitals and the Federal District, the group of these capitals, the five major geographic regions of the country (North, Northeast, Southeast, South and Center-West), besides the country as whole. The sampling process was probabilistic, and the sampling plan was formed by schools (primary sampling units) and classrooms of schools (secondary sampling units). In the case of cities that are not capitals, primary sampling units were the groups of cities, and secondary sampling units were schools; in this case, classrooms were the tertiary sampling units.

In order to correct the impact on variance, the correction factor was used in the sample so that the cluster sampling could result in a similar variance in relation to the simple random sample. Also, in order to correct the sample because the selected individuals did not present the same probability of participating in the sample, as it happens in the simple random sample, weights were attributed to participants and were determined by the opposite of the probability of this person being selected in the cluster sampling.

Therefore, the weight of a specific student for the strata formed by cities that are not capitals was given by the product of the weights of selection in the first stage (groups of cities or primary sampling unit - PSU), the selection of the second stage (school or secondary sampling unit - SSU), and the selection of the third stage (classroom or tertiary sampling unit - TSU). There was correction due to the absence of students who regularly attend school, however, they were absent on the day of the research. Therefore, the weight of the $l$ student, from classroom $k$, from school $j$, from PSU $i$, stratum $h$, was given by the formula:

$$
w_{h i j k}=\frac{T_{h i j}}{n_{h i j}} \frac{F_{h i j k}}{P_{h i j k}} \quad w_{h i j k l}=w_{h i} w_{h i j} w_{h i j k}, l=1,2, \ldots, p_{h i j k} w_{h i}=\frac{T_{h}}{2 T_{h i}} \quad w_{h i j}=\frac{T_{h i}}{n_{h i} T_{h i j}}
$$

In which:

$w_{\text {hi }}$ is the weight of the PSU i of stratum h;

$w_{\text {hij }}$ is the weight of school $\mathrm{j}$, PSU i of stratum h;

$w_{\text {hijk }}$ is the weight of classroom $\mathrm{k}$, school $\mathrm{j}$, from PSU $\mathrm{i}$ of stratum $\mathrm{h}$;

$T_{h}$ is the number of classrooms in stratum $h$;

$T_{h i}$ is the number of classrooms of PSU i, of stratum h;

$T_{\text {hij }}$ is the number of classrooms in school $\mathrm{j}$, from PSU i of stratum h;

$n_{\mathrm{hi}}$ is the sample size of schools from PSU $\mathrm{i}$, of stratum h;

$n_{\text {hij }}$ is the sample size of classrooms of school $\mathrm{j}$, from PSU $\mathrm{i}$, of stratum h;

$P_{\text {hijk }}$ is the number of students who answered from classroom $\mathrm{k}$, school $\mathrm{j}$, from PSU $\mathrm{i}$, of stratum h; 
$F_{\text {hijk }}$ is the number of students attending classroom k, school j, from PSU i, stratum h.

The formula is simpler for strata formed by capitals, since there are only the last two selection stages. The weight of student $l$, from classroom $k$, at school $j$, from stratum $h$, is:

$$
w_{h j k l}=w_{h j} w_{h j k}, l=1,2, \ldots, p_{h j k} w_{h j}=\frac{T_{h}}{n_{h} T_{h j}} w_{h j k}=\frac{T_{h j}}{n_{h j}} \frac{F_{h j k}}{P_{h j k}}
$$

In which:

$w_{h j}$ is the weight of school $\mathrm{j}$, of stratum $\mathrm{h}$;

$w_{\text {hik }}$ is the weight of classroom $\mathrm{k}$, school $\mathrm{j}$, of stratum $\mathrm{h}$;

$T_{h}$ is the number of classrooms of stratum h;

$T_{h j}$ is the number of classrooms of school $\mathrm{j}$, stratum $\mathrm{h}$;

$n_{\mathrm{h}}$ is the sample size of schools in stratum $\mathrm{h}$;

$n_{\mathrm{hj}}$ is the sample size of classrooms in school $\mathrm{j}$, stratum $\mathrm{h}$;

$P_{\mathrm{hjk}}$ is the number of students who answered from classroom $\mathrm{k}$, school $\mathrm{j}$, stratum h;

$\mathrm{F}_{\mathrm{hjk}}$ is the number of students attending classroom $\mathrm{k}$, at school $\mathrm{j}$, of stratum $\mathrm{h}$.

For the weight adjustment, information concerning total classrooms and students enrolled in schools was used, according to data from the School Census 2012, provided by the Ministry of Education (MEC) ${ }^{15}$.

In the selected classrooms, 134,310 students were enrolled in the 9th grade of elementary school, in the daily periods of public or private schools located in urban or rural zones of the Brazilian territory. Out of these, 132,123 students were considered to be frequent, and 110,873 were present in the classroom. A total of 109,104 students answered the study, which represented $83 \%$ of those who were considered to be eligible for the study ${ }^{15}$.

The variable bullying was obtained by the question: "In the past 30 days, how often did any of your school colleagues embarrassed, mocked, made fun of, intimidate or tease you so much and made you feel hurt/upset/annoyed/offended/humiliated?” Answers were categorized as "No" (never, rarely, sometimes) and "Yes" (most of the time, always).

The analysis was guided from a conceptual and multidimensional model (Figure 1) proposed by the causality of bullying, which was composed of sociodemographic and individual aspects related to risk behaviors, such as the use of tobacco, alcohol and drugs and early sexual intercourse, besides characteristics of mental health and family context.

1. Sociodemographic features: sex, age, ethnicity/color, school (public or private).

2. Variables that marked risk behaviors:

- Regular alcohol consumption ("In the past 30 days, how often did you drink at least one glass or dose of alcohol? One dose is equal to a can of beer, a glass of wine, or a dose of cachaça or scotch etc.”); 
Block 1 - Sociodemographic characteristics

Block 2 - Risk behaviors

Block 3 - Mental health

Block 4 - Family context
Have been bullied

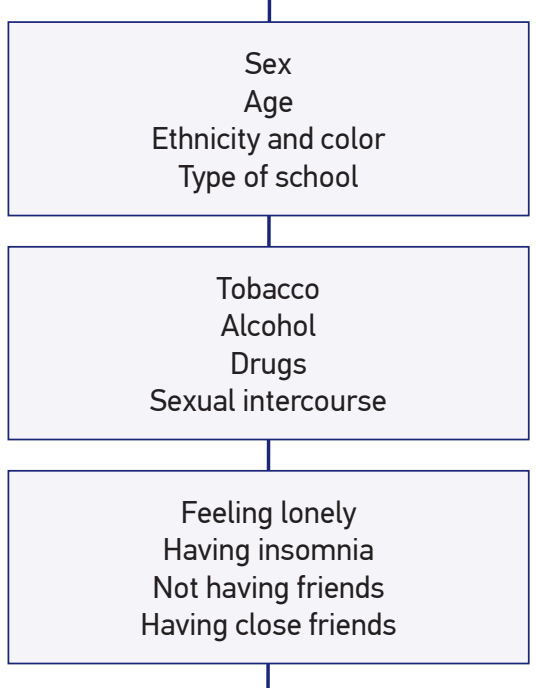

Family supervision free time Missing classes without telling parents Family aggression

Figure 1. Conceptual model proposed for determining the occurrence of bullying in Brazilian school-aged adolescents. National Adolescent School-based Health Survey. Brazil, 2012.

- Regular alcohol use (“In the past 30 days, how often did you smoke cigarettes?”);

- Trying illegal drugs ("Have you ever used any drugs, like marijuana, cocaine, crack, solvent-based glue, narcotics made of chloroform and ether, poppers, ecstasy, oxy etc.?"), which was recodified as "No, I didn't" and "Yes, I did";

- Having intercourse ("Have you ever had intercourse (sex)?"), which was recodified as "Yes" and "No".

3. Mental health markers:

- Feeling lonely, based on the question: "In the past 12 months, how often have you felt lonely?" Options were "No (no, sometimes)" and "Yes (most of the time, always)";

- Insominia: "In the past 12 months, how often were you not able to sleep at night because something was on your mind?" Options were "no (no, sometimes)" and "Yes (most of the time, always)";

- Not having friends: "How many close friends do you have?", categorized into: "none" an "one or more (one, two and more friends)".

4. Family features: it includes aspects related to family supervision, such as parental awareness of school-related or unrelated activities and the presence of family abuse. For the first case, the following questions were used: 
- "In the past 30 days, how often did your parents or parties in charge know about your whereabouts in your free time?" Options were "Yes (most of the time and always)" and "No (never, rarely and sometimes)", and

- "In the past 30 days, how often did you miss school without parental permission", being classified into "Yes (1 to 10 days)" and "No".

- As a marker of family abuse, the following question was used: "In the past 30 days, how often were you physically abused by an adult in your family?" Options were "No" and "Yes (once, twice and more)".

At first, prevalence was estimated with a $95 \%$ confidence interval $(95 \% \mathrm{CI})$. In order to verify associated factors, the univariate analysis was conducted with odds ratio estimates (OR) and their respective confidence intervals. All variables of interest were subsequently inserted in the multivariate model, and those with descriptive level equal to or lower than $5 \%(\mathrm{p} \leq 0.05)$ and with epidemiological base remained. Statistically significant variables $(\mathrm{p}<0.05)$ remained in the final adjusted model. Residue analyses were conducted to verify the model adequacy, using Cook's distance ${ }^{16}$.

In order to correct the different selection probabilities of each student, weights were used to estimate proportions. The analysis was conducted in the software SPSS, version 20, using procedures of the Complex Samples Module, which is adequate for data analyses obtained by a complex sampling plan.

The Study was approved in the Research Ethics Committee of the Ministry of Health, report n. 192/2012, referring to Registration n. 16805 from CONEP/MS, on 27/03/2012.

\section{RESULTS}

The sample was composed of 109,104 students, mostly women (52.2\%), aged between 13 and 15 years old (86\%) and coming from public schools $(82.8 \%)$. The prevalence of bullying was of $7.2 \%(95 \% \mathrm{CI} 6.6-7.9)$.

Table 1 presents the distribution of students according to the report of bullying, which was prevalent among younger students: $8.8 \%$ for those aged less than 13 years old $(\mathrm{OR}=1.40)$, male $(\mathrm{OR}=1.25)$, attending private schools $(\mathrm{OR}=1.08)$, black $(\mathrm{OR}=1.12)$ and mulattos $(\mathrm{OR}=1.15)$. Ethinicity color / yellow $(\mathrm{OR}=0.90)$ was a protective factor in this analysis.

Reports of risk behaviors, such as smoking $(\mathrm{OR}=1.61)$, drinking $(\mathrm{OR}=1.22)$, trying drugs $(\mathrm{OR}=1.44)$, as well as having sexual intercourse $(\mathrm{OR}=1.22)$ increased the chances of reports of being bullied (Table 2).

With regard to the variables corresponding to the domain called mental health, students who felt lonely $(\mathrm{OR}=3.53)$ presented with insomnia $(\mathrm{OR}=3.13)$, and those without friends $(\mathrm{OR}=2.15)$ reported being more bullied when compared to their respective homologues (Table 3 ). 
For family context variables, adolescentes who have experienced physical assault/ Family violence $(\mathrm{OR}=2.65)$ declared to be more bullied, as well as those who reported missing classes without notifying the parents $(\mathrm{OR}=1.33)$. Family supervision, or the report that parents are aware of their children's whereabouts during their free time, had a protective role $(\mathrm{OR}=0.89$ (Table 2$)$.

After the adjustment by all of the variables in the model, ages lower than 13, equal to 13 and 14 years old remained associated $(\mathrm{OR}=1.77 ; 1.50$ and 1.27 , respectively), male gender

Table 1. Frequency of experiencing bullying among Brazilian $9^{\text {th }}$ graders according to age, gender, race/color, schools. Brazil, 2012.

\begin{tabular}{|c|c|c|c|c|c|c|c|}
\hline \multirow{3}{*}{ Variable } & \multicolumn{6}{|c|}{ Being bullied } & \multirow{3}{*}{$p$-value } \\
\hline & \multirow{2}{*}{$\%$} & \multicolumn{2}{|c|}{$95 \% \mathrm{Cl}$} & \multirow{2}{*}{ OR } & \multicolumn{2}{|c|}{$95 \% \mathrm{Cl}$} & \\
\hline & & Inferior & Superior & & Inferior & Superior & \\
\hline General & 7.2 & 6.6 & 7.8 & & & & \\
\hline \multicolumn{8}{|l|}{ Age (years) } \\
\hline$<13$ & 8.8 & 7.0 & 11.0 & 1.40 & 1.09 & 1.79 & 0.009 \\
\hline 13 & 7.9 & 7.4 & 8.6 & 1.24 & 1.15 & 1.35 & $<0.001$ \\
\hline 14 & 7.1 & 6.7 & 7.6 & 1.11 & 1.03 & 1.19 & 0.007 \\
\hline 15 & 6.7 & 6.2 & 7.3 & 1.03 & 0.95 & 1.13 & 0.447 \\
\hline 16 and older & 6.5 & 6.1 & 6.9 & 1.00 & & & \\
\hline \multicolumn{8}{|l|}{ Gender } \\
\hline Male & 7.9 & 7.6 & 8.3 & 1.25 & 1.19 & 1.31 & $<0.001$ \\
\hline Female & 6.5 & 6.3 & 6.7 & 1.00 & & & \\
\hline \multicolumn{8}{|l|}{ Ethnicity } \\
\hline White & 7.3 & 6.5 & 8.2 & 1.00 & & & \\
\hline Black & 8.1 & 7.2 & 9.1 & 1.12 & 1.04 & 1.20 & 0.002 \\
\hline Mulatto & 8.3 & 7.2 & 9.6 & 1.15 & 1.03 & 1.29 & 0.014 \\
\hline Yellow & 6.6 & 5.9 & 7.4 & 0.90 & 0.85 & 0.95 & $<0.001$ \\
\hline Indigenous & 7.9 & 7.0 & 8.8 & 1.09 & 0.96 & 1.23 & 0.195 \\
\hline \multicolumn{8}{|l|}{ School } \\
\hline Private & 7.6 & 7.2 & 8.0 & 1.08 & 1.02 & 1.15 & 0.013 \\
\hline Public & 7.1 & 6.9 & 7.2 & 1.00 & & & \\
\hline
\end{tabular}


$(\mathrm{OR}=1.58)$ being black $(\mathrm{OR}=1.10)$, or yellow, as a protective factors $(\mathrm{OR}=0.94)$, smoking $(\mathrm{OR}=1.11)$, feeling lonely $(\mathrm{OR}=2.66)$, having insomnia $(\mathrm{OR}=1.92)$, not having friends $(\mathrm{OR}=1.71)$, being physically abused by family members $(\mathrm{OR}=2.03)$ and missing classes without notifying the parents $(\mathrm{OR}=1.13)$. The other variables of individual risk behavior (smoking, alcohol, sexual intercourse and drugs) lost significance in the final model and had a negative interaction with each other (data not shown) (Table 4). In the residue analyses of the final model, by using Cook's distance ${ }^{16}$, distributions were adequate.

\section{DISCUSSION}

The prevalence of bullying found in this study was of $7.2 \%$. There were higher chances of bullying among male, younger and black students, and the yellow skin was a protective factor. From the individual risk behaviors, only being a smoker remained in the final model. Mental health variables associated with bullying were feeling lonely, not having friends, reporting insomnia; and, in the family context, the ones who miss classes without notifying their parents and those who reported being physically assaulted by family members.

Table 2. Risk factors associated with bullying among Brazilian $9^{\text {th }}$ graders. Brazil, 2012.

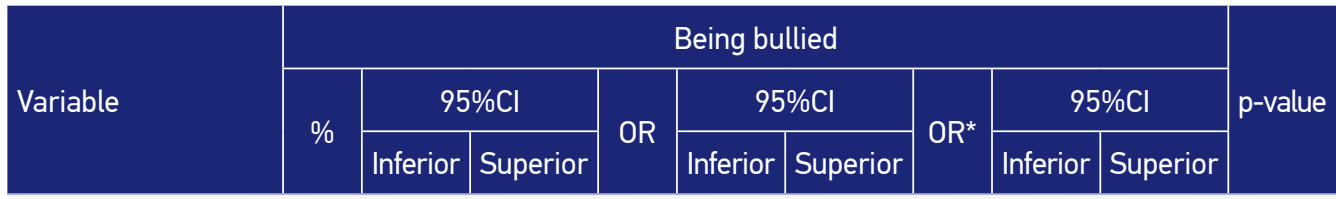

Regular tobacco

\begin{tabular}{l|c|c|c|c|c|c|c|c|c|c|}
\hline No & 9.9 & 7.9 & 12.2 & 1.00 & & & 1.00 & & & \\
\hline Yes & 15.0 & 13.9 & 16.2 & 1.54 & 1.41 & 1.69 & 1.61 & 1.47 & 1.77 & $<0.001$ \\
\hline
\end{tabular}

Regular alcohol

\begin{tabular}{l|c|c|c|c|c|c|c|c|c|c}
\hline No & 9.6 & 7.7 & 12.0 & 1.00 & & & 1.00 & & & \\
\hline Yes & 11.5 & 11.0 & 12.1 & 1.18 & 1.12 & 1.24 & 1.22 & 1.16 & 1.29 & $<0.001$ \\
\hline
\end{tabular}

Trying drugs

\begin{tabular}{l|c|c|c|c|c|c|c|c|c|c|}
\hline No & 9.8 & 7.8 & 12.1 & 1.00 & & & 1.00 & & & \\
\hline Yes & 13.5 & 12.6 & 14.4 & 1.42 & 1.31 & 1.53 & 1.44 & 1.33 & 1.56 & $<0.001$ \\
\hline
\end{tabular}

Sexual intercourse

\begin{tabular}{l|c|c|c|c|c|c|c|c|c|c|}
\hline No & 9.6 & 7.7 & 11.9 & 1.00 & & & 1.00 & & & \\
\hline Yes & 11.5 & 10.9 & 12.0 & 1.19 & 1.13 & 1.25 & 1.22 & 1.15 & 1.28 & $<0.001$ \\
\hline
\end{tabular}

${ }^{*}$ Adjusted for sex and age. 
Table 3. Mental health and family background variables associated with bullying among Brazilian $9^{\text {th }}$ graders. Brazil, 2012.

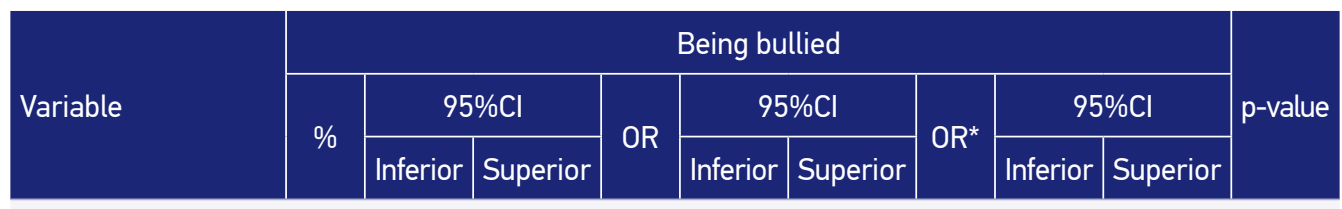

Feeling lonely

\begin{tabular}{|c|c|c|c|c|c|c|c|c|c|c|}
\hline No & 8.6 & 6.9 & 10.8 & 1.00 & & & 1.00 & & & \\
\hline Yes & 25.0 & 24.0 & 26.0 & 3.21 & 3.05 & 3.37 & 3.53 & 3.36 & 3.72 & $<0.001$ \\
\hline \multicolumn{11}{|l|}{ Insomnia } \\
\hline No & 9.8 & 7.8 & 12.1 & 1.00 & & & 1.00 & & & \\
\hline Yes & 25.3 & 24.2 & 26.4 & 2.88 & 2.72 & 3.05 & 3.13 & 2.95 & 3.32 & $<0.001$ \\
\hline \multicolumn{11}{|l|}{ Friends } \\
\hline 1 or more & 9.6 & 8.8 & 10.5 & 1.00 & & & 1.00 & & & \\
\hline None & 18.7 & 15.1 & 22.9 & 2.18 & 1.98 & 2.40 & 2.15 & 1.95 & 2.37 & $<0.001$ \\
\hline \multicolumn{11}{|c|}{ Family aggression } \\
\hline No & 9.1 & 7.3 & 11.3 & 1.00 & & & 1.00 & & & \\
\hline Yes & 20.9 & 20.0 & 21.9 & 2.59 & 2.45 & 2.75 & 2.65 & 2.50 & 2.80 & $<0.001$ \\
\hline \multicolumn{11}{|c|}{ Family supervision } \\
\hline No & 10.7 & 8.6 & 13.3 & 1.00 & & & 1.00 & & & \\
\hline Yes & 9.6 & 9.2 & 10.0 & 0.89 & 0.85 & 0.93 & 0.89 & 0.85 & 0.93 & $<0.001$ \\
\hline \multicolumn{11}{|c|}{ Missing classes } \\
\hline No & 9.6 & 7.7 & 11.9 & 1.00 & & & 1.00 & & & \\
\hline Yes & 12.4 & 11.9 & 13.0 & 1.31 & 1.24 & 1.37 & 1.33 & 1.27 & 1.40 & $<0.001$ \\
\hline
\end{tabular}

${ }^{*}$ Adjusted for sex and age.

Several studies about victimization among children at school age have been published in the past few years ${ }^{3-5,7,17,18}$, but only a few report investigations in the mental health and family contexts. Besides, mental health variables, such as feelings of sadness or desperation, solitude, insomnia and risk behaviors such as the use of tobacco, alcohol and drugs and sexual intercourse, associated with victimization, have been little described in literature.

The prevalence of victimization ranges in several studies and countries. Studies in Europe and North America found a $5-20 \%$ prevalence of bullying ${ }^{5,17}$; in Africa, from $21-40 \%{ }^{18}$, and in Europe, North America and Africa, above $41 \%{ }^{19-22}$. 
Table 4. Final multivariate model of the association of bullying among Brazilian $9^{\text {th }}$ graders Brazil, 2012.

\begin{tabular}{|c|c|c|c|c|}
\hline \multirow{2}{*}{ Variable* } & \multirow{2}{*}{ OR } & \multicolumn{2}{|c|}{$95 \% \mathrm{Cl}$} & \multirow{2}{*}{ p-value } \\
\hline & & Inferior & Superior & \\
\hline \multicolumn{5}{|l|}{ Age (years) } \\
\hline$<13$ & 1.77 & 1.37 & 2.29 & $<0.001$ \\
\hline 13 & 1.50 & 1.38 & 1.63 & $<0.001$ \\
\hline 14 & 1.27 & 1.18 & 1.38 & $<0.001$ \\
\hline 15 & 1.09 & 1.00 & 1.20 & 0.049 \\
\hline 16 and older & 1.00 & & & \\
\hline \multicolumn{5}{|l|}{ Gender } \\
\hline Male & 1.58 & 1.51 & 1.66 & $<0.001$ \\
\hline Female & 1.00 & & & \\
\hline \multicolumn{5}{|l|}{ Ethnicity } \\
\hline White & 1.00 & & & \\
\hline Black & 1.10 & 1.02 & 1.18 & 0.010 \\
\hline Mulatto & 1.12 & 0.99 & 1.26 & 0.063 \\
\hline Yellow & 0.94 & 0.89 & 0.99 & 0.019 \\
\hline Indigenous & 1.05 & 0.92 & 1.19 & 0.464 \\
\hline \multicolumn{5}{|l|}{ Feeling lonely } \\
\hline No & 1.00 & & & \\
\hline Yes & 2.66 & 2.52 & 2.81 & $<0.001$ \\
\hline \multicolumn{5}{|l|}{ Insomnia } \\
\hline No & 1.00 & & & \\
\hline Yes & 1.92 & 1.80 & 2.05 & $<0.001$ \\
\hline
\end{tabular}

Friends

\begin{tabular}{l|l|l|l|l}
\hline 1 or more & 1.00 & & & \\
\hline None & 1.71 & 1.54 & 1.89 & $<0.001$ \\
\hline
\end{tabular}

Family aggression

\begin{tabular}{|l|l|l|l|l}
\hline No & 1.00 & & & \\
\hline Yes & 2.03 & 1.91 & 2.16 & $<0.001$ \\
\hline Missing school & \multicolumn{3}{|l}{} \\
\hline No & 1.00 & & & \\
\hline Yes & 1.13 & 1.07 & 1.19 & $<0.001$ \\
\hline Regular tobacco & 1.00 & & & \\
\hline No & 1.11 & 1.01 & 1.23 & 0.030 \\
\hline Yes & & & \\
\hline
\end{tabular}

${ }^{*}$ Adjusted for all variables in the model. 
Studies about the prevalence of victimization in 19 low and mid-income countries, in the Global School-Based Student Health Survey (GSHS), pointed out to the prevalence variation between $7.8 \%$, in Tajikistan, and $60.9 \%$, in Zambia. The highest prevalence was described among boys and younger students. This variability can be explained by matters related to questions about bullying victimization (temporal difference; assessed perspective - if it is the victim's, the aggressor's, or both; type of question and adopted bullying concept; and answer categorization), or by cultural issues that surround the concept of violence itself.

Most studies about gender and bullying indicate the prevalence of victimization among boys $^{2,23,24}$, which corroborates the findings in this study. However, the study by Ybarra et al. $^{25}$, identifying bullying in the internet, pointed out to higher prevalence among girls, and the study by Costa et al. ${ }^{10}$, conducted in a Brazilian urban center, did not find significant differences among genders.

As to age, in accordance with findings from PeNSE, literature shows higher prevalence of bullying among younger students. In this study, it was more common among students aged less than 15 years old, and the younger they were, the higher the frequency of bullying, as demonstrated in other analyses ${ }^{5,18,26}$. Even though there was no significant difference among ages, Costa et al. ${ }^{10}$ indicate that the place where bullying takes place was different according to age. Younger adolescents reported bullying in the school environment, while older ones included other places in their reports, such as the street, the household and the workplace.

As to mental health, studies have indicated the association between bullying and sadness, despair, loneliness, depression, anxiety, insomnia and suicidal thoughts ${ }^{5,21,26,27}$, besides the worsened psychological status and negative levels of satisfaction towards life ${ }^{10}$, which corroborates the findings in this study, which indicate the higher association (OR) between bullying and feeling lonely. In the United States, a study showed the association between bullying, anxiety and suicidal ideation ${ }^{27}$. Increased anxiety and stress and decreased rest may contribute with reduced health among adolescents. PeNSE also identified the association between bullying, insomnia and lack of friends.

It is worth to mention that, even though some variables related to mental health have been associated with bullying, its similarity with the consequences of bullying itself ${ }^{0}$ leads us to be cautious in the causal nexus of this study, which is an important limitation since this is a cross-sectional study. In other words, since the victim of bullying is usually insecure and passive, such characteristics may awaken aggression and, therefore, perpetuate the situation, once the absence of reciprocity - one of the aspects of bullying - explains the preference of the aggressor for more fragile victims.

Studies in the GSHS have examined the association between victimization and risk behaviors (use of tobacco, alcohol and drugs), and it observed that students who were bullied were more prone to using tobacco than the other students ${ }^{26}$. Higher prevalence rates of alcohol consumption among students who were bullied were found in studies of the United States ${ }^{528}$ and Canada ${ }^{26}$. Higher prevalence rates of illegal drug use were found among bullying victims in studies conducted in the United States ${ }^{5,25,28}$ and Finland ${ }^{23}$. In Brazil, a study conducted in an urban center found higher prevalence of bullying among adolescents 
who reported being involved in fights, use of drugs, drunkenness episodes and tobacco use ${ }^{10}$. The current study indicated association, adjusted by gender and age, for the use of tobacco, alcohol and drugs in the univariate analysis. However, after the inclusion in the final model, only tobacco remained associated. Literature describes the association between alcohol and bullying ${ }^{14,28}$, even though in this study alcohol did not remain in the final model. Studies in the GSHS in Africa show higher levels of sexual activity among students who are victims of bullying $^{22}$; In this study, such an association did not remain in the final model either. Among individual risk behaviors (tobacco, alcohol, sexual intercourse and drugs), only smoking remained associated with bullying in the final model.

No colinearity was detected between the variables in the individual risk behavior domain (data not shown); however, a negative interaction was observed between sexual intercourse and alcohol and drug use. Such an intriguing association can be based on some arguments. The first one is the fact that bullying is more frequent among younger students in the school context, while the use of alcohol, drugs and sexual intercourse are more common among older students, as previously described ${ }^{11,12,15,29,30}$. Besides, the use of alcohol among adolescents occurs in groups of friends, being associated with pleasure, relationships, celebrations, and parties in our culture, therefore being stimulated in social situations ${ }^{31}$. Adolescents who consume alcohol have a more agitated social life, more friends and, consequently, a protective network, which can decrease the victimization caused by bullying. This finding should be further analyzed and discussed in order to understand these hypotheses.

The association between risk behavior and bullying can lead to severe damages to the health of adolescents; besides, it can cause family problems and weaken social networks ${ }^{7}$.

Family supervision had a protective effect for bullying. Studies have described the protective effect of parental control and involvement. The support to children is associated with the protective situation of students in several aspects, therefore preventing violent attitudes, such as being involved in fights and physical wrestles ${ }^{14,32}$, as well as lower prevalence of substance use $^{12,13,33}$. The attitude of missing classes without notifying the parents has been associated with bullying. Likewise, experiences of family aggression have been associated in the final model. Family violence creates in insecure environments, which lead to deep consequences for the physical and mental health of children ${ }^{14,33}$. Other studies indicate that parental atitudes and practices, such as aggression and physical abuse against children and adolescents, are associated to higher prevalence rates of substance use and experimentation ${ }^{34}$. In the study by Costa et al. ${ }^{10}$, victimization by bullying was associated to poorer family perception. For the author, the relationships established in the family context may favor aggressive behaviors, which characterize bullying. The violent family context includes low self-esteem, repeated situations of violence, problems with school performance, violent behaviors and bullying practices $^{14,34}$. PeNSE is the most comprehensive survey conducted with students in Brazil, both concerning the sample and the approached subjects. Since it is a cross-sectional study, it presents some limitations to determine causality. Therefore, even though it seems like bullying victims are more prone to having mental health issues and risk behaviors, it is not possible to relate the temporality or the causality direction for these associations. 


\section{CONCLUSION}

Bullying can range according to age, gender and individual characteristics, besides cultural and social contexts. The associations mentioned here may support education and health professionals, as well as parents and communities in search of measures to prevent this sort of violence. As a dynamic phenomenon, it is related to a complex network of interaction between individuals, families and schools, surrounded by the sociocultural context.

Bullying may affect the physical and the mental health of adolescents, which requires the attention from schools, from parents and the community. Further studies are necessary in order to better understand the differences and the contexts that produce such behaviors. However, the work of health and education professionals in order to identify these types of violence and to prevent them is something to be dealt with currently. This study embraces a dimension that should integrate multiple sectors, both in macrostructural aspects - such as the social public policies - and in the articulation and integration of different sectors and services, from the intersectoral and integral perspective, so it would be possible to define and establish supportive and protective networks.

\section{REFERENCES}

1. Martins, MJ. O problema da violência escolar: Uma clarificação e diferenciação de vários conceitos relacionados. Rev Port Educ 2005; 18(1): 93-105.

2. Malta DC, Silva MA, Mello FCM, Monteiro RA, Silva C, Sardinha LM, et al. Bullying nas escolas brasileiras: resultados Pesquisa Nacional de Saúde do Escolar (PeNSE), 2009. Ciênc Saúde Coletiva 2010; 15(2): 3065-76.

3. Sourander A, Helstela L, Heleinus H, Piha J. Persistence of bullying from childhood to adolescence--a longitudinal 8-year follow-up study. Child Abuse Negl 2000; 24(7): 873-81.

4. Bond L, Carlin JB, Thomas L, Rubin K, Patton G. Does bullying cause emotional problems? A prospective study of young teenagers. BMJ 2001; 323(7311): 480-4.

5. Carlyle KE, Steinman KJ. Demographic differences in the prevalence, co-occurrence, and correlates of adolescent bullying at school. J Sch Health 2007; 77(9): 623-9.

6. Liberal EF, Aires RT, Aires MT, Osório AC. Escola Segura. J. Pediatr 2005; 81(5): s155-63.

7. Organização Mundial de Saúde. Inequalities young people's health: key findings from the Health Behaviour in School-aged Children (HBSC) 2005/2006 survey fact sheet. Copenhagen: WHO; 2008 (Health Policy for Children and Adolescents, No. 5).

8. Fischer RM. Relatório de Pesquisa "Bullying escolar no Brasil”. Centro de Empreendedorismo Social e
Administração em Terceiro Setor. São Paulo (SP): Fundação Instituto de Administração; 2010.

9. Fleming LC, Kathryn HJ. Bullying among middleschool students in low and middle income countries. Health Promot Int 2010; 25(1): 73-84.

10. Costa MR. Bullying entre adolescentes de um centro urbano: estudo Saúde em Beagá [tese de mestrado]. Belo Horizonte (MG): Faculdade de Medicina da Universidade Federal de Minas Gerais; 2012.

11. Brasil. Instituto Brasileiro de Geografia e Estatística. Pesquisa Nacional de Saude do Escolar (PeNSE) 2009. Rio de Janeiro: IBGE; 2009.

12. Malta DC, Porto DL, Melo FC, Monteiro RA, Sardinha LM, Lessa BH. Família e proteção ao uso de tabaco, álcool e drogas em adolescentes, Pesquisa Nacional de Saúde dos Escolares. Rev Bras Epidemiol 2011; 14(1): 166-77.

13. Barreto SM, Giattil L, Casado L, Moura L, Crespo C, Malta DC. Exposição ao tabagismo entre escolares no Brasil. Ciênc Saúde Coletiva 2010; 15(2): 3027-34.

14. Andrade SC, Yokota RT, Sá NN, Silva MM, Araújo $\mathrm{WN}$, Mascarenhas MM, et al. Relação entre violência física, consumo de álcool e outras drogas e bullying entre adolescentes escolares brasileiros. Cad Saúde Pública 2012; 28(9): 1725-36. 
15. Brasil. Instituto Brasileiro de Geografia e Estatística. Pesquisa Nacional de Saude do Escolar (PeNSE) 2012. Rio de Janeiro: IBGE; 2013.

16. Hosmer DW, Lemeshow S. Applied Logistic Regression. $2^{\text {nd }}$ ed. New York: Wiley; 2000.

17. Schnohr C, Niclasen BV. Bullying among Greenlandic schoolchildren: development since 1994 and relations to health and health behavior. Int J Circumpolar Health 2006; 65(4): 305-12.

18. Liang H, Flisher AJ, Lombard CJ. Bullying, violence, and risk behavior in South African school students. Child Abuse Negl 2007; 31(2): 161-71.

19. Nansel TR, Craig W, Overpeck MD, Health Behaviour in School-aged Children Bullying Analysis Working Group. Cross-national consistency in the relationship between bullying behaviors and psychosocial adjustment. Arch Pediatr Adolesc Med 2004; 158(8): 730-6.

20. Borup I, Holstein BE. Schoolchildren who are victims of bullying report benefit from health dialogues with the school health nurse. Health Educ J 2007; 66: 58-67.

21. Nylund K, Bellmore A, Nishina A, Graham S. Subtypes, severity, and structural stability of peer victimization: what does latent class analysis say? Child Dev 2007; 78(6): 1706-22.

22. Rudatsikira E, Siziya S, Kazembe LN, Muula AS. Prevalence and associated factors of physical fighting among school-going adolescents in Namibia. Ann Gen Psychiatry 2007; 6:18.

23. Kaltiala-Heino R, Rimpelä M, Rantanen $\mathrm{P}$, Rimpelä A. Bullying at school: an indicator of adolescents at risk for mental disorders. J Adolesc 2000; 23(6): 661-74.

24. Klomek AB, Marroco F, Kleinman M, Schnofeld IS, Gould MS. Peer victimization, depression, and suicidiality in adolescents. Suicide Life Threat Behav 2008; 38(2): 166-80.

25. Ybarra ML, Diener-West M, Leaf PJ. Examining the overlap in internet harassment and school bullying: implications for school intervention. J Adolesc Health 2007; 41(6 Suppl 1): S42-50.
26. Morris EB, Zhang B, Bondy SJ. Bullying and smoking: examining the relationships in Ontario adolescents. J Sch Health 2006; 76(9): 465-70.

27. Klomek AB, Marrocco F, Kleinman M, Schonfeld IS, Gould MS. Bullying, depression, and suicidality in adolescents. J Am Acad Child Adolesc Psychiatry 2007; 46(1): 40-9.

28. Tharp-Taylor S, Haviland A, D’Amico EJ. Victimization from mental and physical bullying and substance use in early adolescence. Addict Behav 2009; 34(6-7): 561-7

29. Oliveira-Campos M, Giatti L, Malta D, Barreto SM. Contextual factors associated with sexual behavior among Brazilian adolescents. Ann Epidemiol 2013; 23(10): 629-35.

30. Reddy P, Resnicow K, Omardien R, Kambaran N. Prevalence and correlates of substance use among high school students in South Africa and the United States. Am J Public Health 2007; 97(10): 1859-64.

31. Malta DC, Mascarenhas MDM, Porto DL, Duarte EA, Sardinha LM, Barreto SM et al . Prevalência do consumo de álcool e drogas entre adolescentes: análise dos dados da Pesquisa Nacional de Saúde Escolar. Rev Bras. Epidemiol 2011; 14(1): 136-46.

32. Muula AS, Herring P, Siziya S, Rudatsikira E. Bullying victimization and physical fighting among Venezuelan adolescents in Barinas: results from the Global School-Based Health Survey 2003. Ital J Pediatr 2009; 35(1): 38.

33. Youngblade LM, Theokas C, Schulenberg J, Curry L, Huang IC, Novak M. Risk and promotive factors in families, schools, and communities: a contextual model of positive youth development in adolescence. Pediatrics 2007; 119(1): S47-53

34. Paiva FS, Rozani TM. Estilos parentais e consumo de drogas entre adolescentes: revisão sistemática. Psicol Estud 2009; 14(1): 177-83

Received on: 11/14/2013

Final version presented on: 01/22/2014

Accepted on: 01/24/2014 